\title{
THE PHENOMENOLOGY OF SPE BOUNDARIES
}

\author{
MAŁGORZATA HAŁADEWICZ-GRZELAK
}

\section{Introduction}

Kiklewicz (2002: 271) points out that dialectic cooperation of content and form of signs is the basis and inner mechanism of dynamics of both styles of writing and linguistic-philosophical paradigms. In his study devoted to the dynamics of linguistic paradigms (cf. e.g. Kiklewicz, 2007, Chapter I), the scholar further emphasizes that the problem of paradigms in humanities has a causative character: it relates to various forms of social consciousness (Kiklewicz, 2007: 22). The crucial division between paradigms is posited to be the dyad communicative versus cognitive models (Kiklewicz, 2007: 40). "Communicativism entails the physical status of its objects - real existence of the speech acts and texts (Korżyk, $1999,16)$ while the object of cognitive linguistics is granted to a given community and encoded in a language, an abstract, ideal system of the conceptualization of the world" (Kiklewicz, 2007: 43). The same point has been emphasized by Kuźniak (e.g. 2013): generativism used to be considered a cognitive theory, the move from the observed data to modelling abstract knowledge in the mind of the speaker. On this take, generative grammar as proposed in the 60's in a series of publications by Noam Chomsky, is an example of cognitive revolution. ${ }^{1}$

This paper is contribution to the ongoing discussion on paradigm dynamics by proposing a critical appraisal of the boundary systems proposed in the groundbreaking Sound Patterns of English (henceforth SPE). However, it is

\footnotetext{
${ }^{1}$ See also a discussion on the heteronomic status of the object of linguistics and references therein in: Wąsik (2005).
} 
a very particular type of modelling of linguistic knowledge. The book, published in 1968 by Chomsky and Halle, relies on the postulate that "what the hearer 'hears' is what is internally generated by the rules. That is, he will 'hear' the phonetic shape determined by the postulated syntactic structure and the internalized rules" (Chomsky and Halle, 1968: 24). ${ }^{2}$ Furthermore, "the lexical representation is abstract in a very clear sense; it relates to the signal only indirectly, through the medium of the rules of phonological interpretation that apply to it as determined by its intrinsic abstract representation and the surface structure in which it appears" (Chomsky and Halle, 1968: 12). Most crucially,

[t]he rules of the grammar operate in a mechanical fashion, one might think of them as instructions that might be given to mindless robot, incapable of exercising any judgment or imagination in their application. Any ambiguity or inexplicitness in the statement of the rules must in principle be eliminated, since the receiver of the instructions is assumed to be incapable of using intelligence to fill in gaps or correct errors. To the extent that rules do not meet this standard of explicitness and precision, they fail to express the linguisitc facts" (Chomsky and Halle, 1969: 60).

The fallacies implicated in such refutation of the importance of semantics have been pointed out frequently within various perspectives (e.g. Wierzbicka, 1978). From the point of view of model post-generative phonology the shortcomings of the $S P E$ are obvious: most contemporary phonological models (e.g. Feature Geometry, CVCV, Optimality Theory have come to existence with the view that phonological features need not be limited to a segment (one tier), but spread over larger units (as shown in e.g. phonological processes of palatalizations or vowel harmony, e.g. Goldsmith et al., for an overview) or can be inscribed by an interplay of lateral relations (e.g. CVCV). OT explicitly assumes that we do not have any evidence for the existence of a rule component: all we have direct access to are output realizations (see, e.g. Archangeli, 1999).

The present work, admitting the validity of all these contestations, proposes a phenomenological enquiry into the phenomenological status of the $S P E$ content that did survive into subsequent models. As Scheer argues (EGG summer school classes in Olomouc 2006, hand-out available at: www.unice.fr/tobias $/ \mathrm{htm}$; see also Scheer, 2011 and his classes given at Ealing 2007, at École d'Automne de Linguistique), the SPE set standards for 40 years, because phonologists are still

\footnotetext{
${ }^{2}$ N. Chomsky and M. Halle (1968) assume there are three features in the cycle: i) the cycle, as a phonological interpretation, applies within a word and across word boundaries; ii) it proceeds in steps, from the most embedded structures to the least embedded ones: "the phonological rules firstly apply to the maximal strings that contain no brackets, and that after all relevant rules have applied, the innermost brackets are erased; the rules then reapply to maximal strings containing no brackets, and again innermost brackets are erased after this application; and so on, until the maximal domain of phonological process is reached" (Chomsky - Halle, 1968: 15), iii) the phonological cycle is natural and relies on the speaker's intuition.
} 
using what SPE has done; even with the support of the SPE linguistic examples [emphasis mine, MHG]. Reading through the interface literature one can find various ideas from SPE under different names, without referring to the original source (the readjustment component is one example, or boundaries as phases, also Class 1 and Class affixes in Lexical phonology. ${ }^{3}$ What follows, though SPE might be currently forgotten as the original source of ideas, it is, at the same time, still the backbone of generative thought. The main research goal of this paper stems from the assumption that, although many of the $S P E$ proposals have been overtly contested, also a lot of them have been covertly endorsed. This point is addressed through the analysis of the elusive nature of SPE boundaries and of the concept of 'a formative' as a formal substitute for the cognitive motivation.

There is also another dimension to the present discussion: the work proposed by Bańczerowski (2004) on the axiomatic / quasi-axiomatic status of linguisitc theories. According to this scholar, quasi-axiomatic theories can be divided into two main strands: programmed axiomatization and the calculization of grammars (ibidem: 22). Quasi -axiomatic theories, in contradistinction to the axiomatic ones, are, according to this scholar, characterized by several deficiencies, such as the lack of clear-cut difference between primordial and derived terms, the lack of difference between axioms and theorems, the lack of characterization of terms occurring in the definitions with the help of adequate axioms (Bańczerowski, 2004: 22). Within the option of calculization of grammars, Bańczerowski proposes that pure calculations can't be considered to be theories of natural language because they do not formulate theorems about it. Accordingly the scholar proposes that grammars which are calculi, can simply be called calculative or

\footnotetext{
${ }^{3}$ To recall briefly, upgrading on SPE's boundaries ('\#', '+' and '=', applying to all English affixes), English suffixes are traditionally divided into two classes: stress-shifting (stem-affecting, i.e. those that shift stress one syllable left; which in SPE went with a "+" boundary e.g. $\{-$ ity $\}$ ) and stress-neutral (stem-neutral, e.g. \{-ness\}- those that do not effectuate such a shift, in SPE marked with a "\#” [hedge]). For example, Lexical Phonology suggested the level-ordered affixation (e.g. Siegel 1974; Mohanan, 1986). It implies that Class 1 affixes are added to the root at the initial level of word-structure building. Class 2 affixes, in turn, are added after all first level affixation has taken place (cf. Carr, 1993). Stress is a level 1 rule. The exemplary Level 1 affixes are: \{-ity, -al, -ence, -eer, dis-, etc.\}. Level 2 affixes include: \{-ship, -ness, -hood, -ism, -ist, -like, regular inflection, etc. . There is also a notion of a 'cranberry' morpheme: a lexicalized unproductive bound morpheme. It does not possess any specific grammatical function, its 'synchronic meaning being reduced to its distinctive feature, it serves to discriminate words (Bussmann, 1996: 414). For example, $\{$-cran $\}$ in cran+berry is considered 'cranberry', just as constituent morphemes in per+mit, sub+mit, com +mit , since they do not have an identifiable content nor a particular function. Finally, we could mention the distinction between 'clitic' boundary $(+)$ (which is considered to be a weak boundary) and a word boundary (\#), which is usually attributed to SPE.

We might observe in passing regarding SPE terminology that it is not true that SPE did not use the concept of syllable. For example, on page 101 'syllable' is used as a term defining the scope of the application of a rule.
} 
algorithmic grammars. They fall into two types: generative grammars and categorical grammars (ibidem: 27). ${ }^{4}$ What is more, similarly to the simplification grammars, generative rules cannot be considered statements about natural language. Further on, Bańczerowski emphasises that refusing the calculative grammar the status of the theory is not meant to diminish their linguisitc importance but to rectify their epistemological status. Along these lines, this paper aims to explore some of the epistemological and phenomenological issues implicit in a small portion of Chomsky's theory: the category of boundaries.

The discussion will start by tracking relevant formulations which Chomsky and Halle included in their book. The task will be quite demanding since there is little theoretical guidance, neither on the analytical terms nor the categorizations provided in SPE: most current terminology is basically interpretations and amendments. The next section will adumbrate sample specimens of SPE representations (notations as in the original), and the paper will conclude with a discussion of some of the isolated and problematic issues lurking behind the assigned boundary symbols.

\section{Boundaries and formatives: terminological status}

As Scheer (2011) emphasizes, there are two ways of representing morphosyntactic information in phonology (two ways of talking to phonology): one procedural, the other representational. The representational way consists of a procedure whereby morphemes are pieced together, and then an object is sent

\footnotetext{
${ }^{4}$ We might note here a very important observation that Bańczerowski makes and which I would like to quote here in original in extenso: "Porównanie gramatyk generatywnych z gramatykami sprawdzającymi prowadzi z konieczności do wniosku, że oba te rodzaje gramatyk po prostu się uzupełniają. Są one właściwie dwoma przejawami jednej i tej samej gramatyki kalkulatywnej. Wobec tego nie można traktować ich rozłącznie, gdyż dopiero razem tworzą spójną całość. Mówiąc ogólnie, Ajdukiewicz wychodzi od ciągu symboli kategorialnych reprezentujących wyrazy będące składnikami jakiegoś zdania i stosując reguły upraszczania, dochodzi do symbolu reprezentującego kategorię zdania. Chomsky, na odwrót, wychodzi od symboli reprezentujących kategorię zdania i stosując reguły generatywne, dochodzi do ciągu symboli reprezentujących poszczególne wyrazy będące składnikami jakiegoś zdania. Tak więc, Chomsky w naturalny sposób uzupełnił jedynie koncepcję Ajdukiewicza w tym sensie, że wydobył z niej na światło dzienne to, co i tak było w niej implicite zawarte. Na tą pierwszą ewentualność wydaje się skazywać również następujące słowa batoga: 'Zauważyć wypada, że Chomsky twórca koncepcji gramatyk generatywnych, starannie unika cytowania Ajdukiewicza, a także dla większej oryginalności porzucił jego znakomitą symbolikę na rzecz własnej, choć obarczonej licznymi błędami. Nie ulega jednak wątpliwości, że Chomsky znał prace Ajdukiewicza, która na początku lat 50-tych (a więc przed debiutem Chomskiego) była w USA głośna i dostępna w przekładzie angielskim' (Batóg, 1989: 80)'. Dobrze byłoby, gdyby przynajmniej językoznawcy z rodzinnego kraju Ajdukiewicza o tym pamiętali" (Bańczerowski, 2004: 29f).
} 
to phonology on top of these morphemic pieces: e.g. a hedge mark (\#), which is not phonological but morphosyntactic information. The procedural way, on the other hand, is known as the transformational cycle, the phonological cycle, phases, etc. (all originating in the paper by Chomsky, Halle and Lukoff in 1956). SPE's boundaries can be considered examples of representational devices.

Although \# (hedge mark) has been discussed often and exhaustively (cf. Scheer, 2011 for relevant data), not much attention seems to have been devoted to the phenomenology of SPE boundaries per se. To recall briefly, boundaries were introduced to upgrade structuralist juncture phonemes, "since junctures are introduced for the purpose of reducing the number of physical features that must be recognized as phonemic, we do not require that every morpheme boundary be marked by a juncture" (Chomsky et al. 1956: 68).

$S P E$ uses three qualitative boundary distinctions: "\#”, "+" and "=". These boundaries are defined in terms of features, just like segments. One crucial boundary feature is being [-segment] (that is, being devoid of phonetic content). Among the features of a boundary system there is one, "FB" (formative boundary), that is of key importance. In Chomsky and Halle's formulation,

only a single boundary is marked [ $+\mathrm{FB}]$. This boundary, which we will designate with the symbol + , appears between final segment of one formative and the initial segment of the following formative. We can think of it as being inserted in this position in terminal string by a general convention. All other boundaries are marked [-FB]. [footnote 7: in our formulation, formative boundary never is preceded or followed by a boundary but must be bounded on both sides by segments.]. One of the non FB boundaries is the unit \# that appears automatically before and after a word and in sentence initial and sentence final position. We will also have the occasion to refer to another boundary, which we will denote by a symbol $=$. In our terms, the unit $=$ must be distinguished from \# by some feature, let us say, the feature "WB " (word boundary). Thus the symbol + stands for the feature complex [-segment, +FB, WB], \# stand for the feature complex [-segment, -FB, $+\mathrm{WB}]$, and = for the feature complex [-segment, $-\mathrm{FB},-\mathrm{WB}]$. We assign very special status to formative boundary in the following way. We assume that the presence of + boundary can be marked in a rule, but that the absence of + cannot be marked in a rule (Chomsky and Halle, 1968: 66).

Recalling that phonology operates on a linear string of segments composed of features, then SPE boundaries are segments with intrinsic features of varying status, depending on whether they delineate a word boundary [+WB] or a formative boundary [ $+\mathrm{FB}]$. The hedge mark ('\#') is a straightforward marking of a word boundary, but it also accompanies some derivational suffixes. The boundary '\#' is distributed over the linear phonological string, carrying morphosyntactic information. It is inserted at the beginning and at the end of each major category, for example, verbs, nouns, adverbs on both sides of higher constituents dominating major categories, such as NPs or VPs (Chomsky and Halle, 1968: 366f). 
What is really intriguing, however, is the phenomenology of the remaining two boundaries: "+" and "=". Both denote morphological boundaries and both are recorded in the lexicon. As such, they do not carry syntactic information. The first is assumed to be the morphological default, occurring within and outside of words, and the latter later came to be called a marker of 'cranberry morphemes' and of learned words (cf. footnote 2 ). ${ }^{5}$ However, in reality, the distinction between the two, just as a unanimous demarcation what is a cranberry morpheme, is not that clear at. Perhaps due to these ambiguities, '=' seems to have fallen into oblivion, in both retrospective work on SPE and contemporary morphological reformulations. The subsequent analysis will concentrate precisely on this particular type of boundary, which allegedly marks cranberry morphemes (learned words) in SPE.

As is evident from the extended quote above, the key difference between the three boundary types lies in the status of combining formatives: the feature [-formative boundary] is a unique way to distinguish between ' + ' and ' $=$ '. Yet this key notion, of a formative, is never clearly defined in SPE. Throughout the book, formatives are just referred to indirectly, e.g., "[t]here are many verbs in English that are morphologically analyzable into one of the prefixes trans-, per-, con- etc., followed by a stem such as -fer, -mit, -cede, -cur or -pel. (...). The stress placement rules must assign primary stress to the final formative [emphasis added, MHG] in these words, regardless of whether it contains a weak or a strong cluster" (Chomsky and Halle, 1968: 94.). In this respect, e.g. $/ \mathrm{iN}=\mathrm{dikAt}+\mathrm{iv} /, / \mathrm{kon}=\mathrm{relAt}+\mathrm{iv} /{ }^{6}$ are called prefix-stem forms by the authors. So they are formatives, but SPE does not address the question why formatives cannot carry the 'formative' feature boundary-wise.

On another occasion formatives are described as minimal elements of a string which the phonological component takes as its input. They are originally provided by the lexicon (one part of the syntactic elements of grammar). Formatives might then undergo slight modification as per the readjustment rules. Moreover, "[i]n the lexicon, each formative must be represented in such a way as to determine precisely how the rules of the phonological component will operate on it, in each context it might appear" (Chomsky and Halle, 1968: 164). Finally, "[c]ertain formatives with nonhigh vowels are lexically marked as excluded from this tensing rule, e.g. -cede" (Chomsky and Halle, 1968: 182). But, referring on to morphs of the type \{-cede\} on another occasion, the authors observe that since these stems and prefixes are generally not independent words or even separate lexical items, there is no \# in this position. "Rather, we expect

\footnotetext{
${ }^{5} S P E$ did not use the word 'clitic'.

${ }^{6}$ All underlying representations are taken from the original source, MHG.
} 
to find the boundary which, in terms of feature analysis is $[-\mathrm{FB},-\mathrm{WB}]$ that is, distinct from + and \#" (Chomsky and Halle, 1968: 94). We can see thus a support for Bańczerowski's quasi-axiomatic category. To recall, Bańczerowski (2004: 19), basing on the work of Batóg or Tarski, enumerates four basic determinants of an axiomatic theory, the second point of which stipulates that in a truly axiomatic theory no term can be used unless it has been properly defined before or it can be derived from the basic terms.

Other particular feature of SPE boundaries is that they can mutate one onto another, which the authors explicitly admit, e.g. footnote 91 :

however, the main stress rule (102) will not apply as required in the second cycle of (138) unless \# is simplified to $+(\ldots)$. We therefore assume that an ad hoc readjustment rule replaces \# by + before -Ory and -Ary. (..).Notice incidentally that a rule replacing \# by + is needed to account for all cases where the distribution of \# does not accord with the syntactically derived surface structure. This is the case of the affix -ion, the /y/ realization of the nominalization element in advocacy, and so on we have + boundary instead of \# which might be expected on the syntactic grounds, the effect being that the affix in question is not neutral with respect to stress placement (Chomsky and Halle, 1968: 134).

Summarizing what has been disclosed so far, for Chomsky and Halle, " $=$ " is overtly "an informal abbreviatory notation for the feature set [-segment -FB WB]" (ibid.: 94). In 'street-wise' talk, here, Chomsky and Halle introduce into English phonology an entity whose only property and raison d'etre is being neither a segment nor a '+' nor a '\#': i.e. being a phonological naught. This 'naught' has, at the same time, some metaphysical substance, since it is usually introduced by the readjustment rules. The entity is specified as a [-formative boundary] yet, from what SPE has to say about formatives, roots such as -fer, -mit and -cede, like stems of type inn, are formatives. There is no explicit mention of what is the criterion for being or not being a formative, and hence for assigning ' $=$ '. This gives ground to argue that $S P E^{\text {' }}+$ ' and ' $=$ ' distinction represents nothing less than a deliberate and considered attempt to introduce mathematical operators into linguistic analysis. They are used mathematically since they function as sort of coefficient, the introduction of which can change the final result into the output which is desired by an analyst. Let us now inspect the relevant underlying representations and see whether any generalizations regarding the assignment of ' $=$ ' versus ' + ' can be made.

\section{Boundaries in underlying representations}

Below is a sample adumbration of underlying representations that I took at random from SPE (notations as in the original), plus my own minor queries: 
$/ \mathrm{pH}=\mathrm{mit} /, \quad / \mathrm{de}=\mathrm{trr} /, \quad$ træns $=\mathrm{f} \mathrm{Hr} /, /$ tele + graph $+\mathrm{y} /, \quad /$ para + site/, /mini + ster/, /huNgr+y/, /pævil+iV̌n/, /æs +iæ/, / /con=cept+u+al/, /con=teplAt+iv/, but /conchology/ without the '=', /koN=pre+heNd/ (in two versions, actually, on page 96 is $/ \mathrm{c} \supset \mathrm{N}=$ pre $=$ heNd/, /inter $=$ cept $/$, /tele + skOp/, /iN $=\operatorname{dikAt}+\mathrm{iv} /$, /coN $=$ ment/, /pre $=\mathrm{sId}+$ ent $+\mathrm{y} /$. /contra $=$ dict/ $[$ why not $\operatorname{con}=$ tra $=\operatorname{dict} /$ ? ], $/ \mathrm{iNter}=\mathrm{l} \mathrm{kk} /[$ why not in=ter=lok/], /mono+genesis/, /monograph/, /auto+mobile/, reduce /re=duke/, /pro=fes +Or +i/, /ana+lIz\#able/ /convent $+\mathrm{iV} n$ /, $\left.{ }_{\mathrm{N}}\left[\mathrm{v}[\text { indemn }+\mathrm{i}+\mathrm{fIk}]_{\mathrm{V}} \mathrm{At}\right]+\breve{\mathrm{V}}\right]_{\mathrm{N}},\left[_{\mathrm{N}}\left[\mathrm{v}[\operatorname{advocAt}]_{\mathrm{V}} \mathrm{y}\right]_{\mathrm{N}}, / \operatorname{arito}+\mathrm{krat}+\mathrm{y} /,\left[_{\mathrm{A}}\left[\mathrm{v}[\mathrm{ad}=\mathrm{vIs}]_{\mathrm{V}} \mathrm{Or}+\mathrm{y}\right]_{\mathrm{A}}\right.\right.$, /industr+y/,

Even this exemplary sample begs a couple of questions while trying to extract a general principle via which boundaries are assigned.

i) there is no ' $=$ ' boundary at all in predatory. But there is one before $\{$-pre- $\}$ in comprehend. Interestingly, here is "=" in e.g. chimpanz=ee., hence '=' cannot be said to refer to (some!) Romance forms.

ii) How is $\{$ mono- $\}$ or $\{$ tele- $\}$ different from $\{$ in- $\}$, \{inter- $\}$ and \{contra- $\}$ (the former carries a "+" and the latter a "=" ? If the criterion is being a content morpheme, then contra in the synchronic lexicon might have an even clearer and separate semantic load than tele. ${ }^{7}$ The only distinction is that tele and mono are of Greek origin. But, on the other hand, chimpanzee is not Latinate, it does not even have a PIE root, and yet it goes with ' $=$ '. Orthodoxy, does not have a ' $=$ ' or any boundary after ortho at all, yet there is a ' $=$ ' after $\{$ pro- $\}$ in professor.

iii) Monograph has no boundary at all while monogenesis has a '\#' boundary (mono genes+is). "This analysis identifies -graph as a stem and -genesis as a noun which is an independent word and assigns mono- to no category at all" (Chomsky and Halle, 1968: 100). Why can't graph be an independent noun, apart from being a stem? Secondly, are not stems supposed to be individual words by definition?

iv) "There is nothing particularly surprising about the fact that conventional orthography is, as these examples suggest, a near optimal system for the lexical representation of English words" (Chomsky and Halle, 1968: 49). So why does correlative have underlying / k⿰N/? (Chomsky and Halle, 1968: 134). It used to be there of course etymologically but it is recoverable only through the etymological dictionaries, definitely not by a synchronic grammar of a user of English.

v) Contrition has an underlying representation without ' $=$ ', just as corollary has the presentation / $\mathrm{korOl}+\mathrm{Ar}+\mathrm{y} /($ rather than $/ \mathrm{korV̌l}+\mathrm{Ar}+\mathrm{y} /)$ (ibid.: 137). This is etymologically correct because, according to etymological sources, corollary has never featured a $\{c o n-\}$ prefix. Yet, on

\footnotetext{
${ }^{7}$ According to etymology, contra comes from 'cum + tra' (Skeat, 1993: 92; see also Cummings, 1989).
} 
p.142, compensatory is in the same class of underlying representations as derogatory and oscillatory and the rules make explicit reference to '=' (-FB) in that type; hence, logically, the underlying representation of oscillatory must somewhere contain ' $=$ '. But no representation is provided, neither is there an explanation of where exactly this '='boundary should be placed in oscillatory and why: after $\{$ os- $\}$ or $\{$ osci- $\}$ ?

vi) compensatory is related to anticipatory but anticipatory cannot have '=' since $\{$ anti- $\}$ is a separate word and must have '\#', while inflammatory has ' $=$ '. We must recall though that $\{$ inter- $\}$ and $\{$ contra- $\}$ go with ' $=$ '.

vii) $\left[_{\mathrm{A}}\left[\mathrm{v}[\text { supervIs }]_{\mathrm{V}} \mathrm{Or}+\mathrm{y}\right]_{\mathrm{A}}\right.$ does not have any boundary after \{super- $\}$, $\left[_{\mathrm{N}}\left[\mathrm{V}\left[{ }_{\mathrm{S}} \mathrm{koment}\right]_{\mathrm{S}}\right]_{\mathrm{V}} \mathrm{Ar}+\mathrm{y}\right]_{\mathrm{N}}\left(\mathrm{p} .144 \text {, predatory is }{ }_{\mathrm{A}} \text { pred }+\mathrm{At}+\mathrm{Or}+\mathrm{y}\right]_{\mathrm{A}}$ migr + at + or $+y],\left[{ }_{A}\left[{ }_{\mathrm{v}}[\mathrm{koN}=\mathrm{peNsAt}]_{\mathrm{V}} \mathrm{Or}+\mathrm{y}\right]_{\mathrm{A}},\left[_{\mathrm{A}}\left[\mathrm{v}[\mathrm{aNticipAt}]_{\mathrm{V}} \mathrm{Or}+\mathrm{y}\right]_{\mathrm{A}}\right.\right.$ dysentery /disVntAr+y / etymologically dys + entera).

viii) Since Chomsky and Halle rely so heavily on etymology, they cannot disregard the fact that there lexemes given as SPE'e examples for these boundaries were Latinate loans. Yet, they cannot get round the issue completely. Romance etymology is mentioned in passing, in two places. 'Romance derivational processes' are mentioned on p. 150 in a footnote: (Chomsky and Halle, 1968: 150 footnote) "a word such as lucid is only an apparent exception. We can derive this from an underlying representation /luc $+\mathrm{id} /$ where $/ \mathrm{c} /$ as a variant of $/ \mathrm{k} /$ that undergoes Romance derivational processes becomes /s/ when followed by a nonlow nonback vowel, after the intervocalic /s/ voicing rule has applied". 8 The question is why lucid does not have a '=' as that is a Romance lexeme? abscissa is represented by ' $=$ ' in perfect accordance with its etymology, although it would appear that it involves a prefix $\{a b-\}$.

ix) roots such as -cede are actually defined as formatives in SPE, e.g. "Certain formatives with nonhigh vowels are lexically marked as excluded from this tensing rule, e.g. -cede" (Chomsky and Halle, 1968: 182). The question then again arises as to why, e.g., concede goes with a boundary which is marked as non-formative?

$\mathrm{x}$ ) absolute does not have a boundary according to SPE, although, just like absolve, it is a Latinate compound.

\footnotetext{
${ }^{8}$ There is also another mention of Romance superstata on a footnote on page 48, in the discussion of the Rounding Adjustment Rule, where, discussing the representation of courage Chomsky and Halle point out, "that the better underlying representation would be corcege, where $c$ stands for a symbol identical in its feature composition as $k$ except that it appears in a lexically designated class of forms that undergo certain syntactic and phonological processes (i.e. they take derivational affixes of the Romance and Greek systems and undergo rules such as (72)" Chomsky and Halle, 1968: 48). Authors are here talking about the rule that later came to be poetically called Velar Softening and is known widely across all phonological systems as a natural phonological process of palatalization.
} 
xi) the "=" in conceptual, chimpanzee, professor and presidency also defies a possible classification where ' $=$ ' goes with complex verbs only.

xii) isolated examples such as indicative (p. 128) are given two possible representations: with ' $=$ ' or without it.

Finally, let us recall the passage in SPE where the English /s/ voicing rule is formulated:

Case (c) applies when the orthography has $x$ in such words as exist, examine, auxiliary, exasperate. In post stress position, as in axis and maxillary, the cluster remains unvoiced. Notice, however, that the voicing does not apply in hexameter, toxicity, annexation, and in general, when the [ks] cluster is final in the formative. This exception requires a readjustment rule, which assigns the feature [-rule (119)] to /s/ in the context k_+. (Chomsky and Halle, 1968: 228-229).

The rule clearly implies that words such as e. g. exist do not carry ANY boundary at all, whether + or $=$ : logically, if there is a boundary in de=sign, $r e=s i s t$, hex=ameter, (or hex + ameter, or hex $+a+$ meter SPE gives no indication of a boundary split in such cases), the lack of the morphemic status of $\{$ ex- $\}$ should at least be motivated somehow. But, earlier on SPE says that "[w]e have to rely on (67) to account for the fact that that prefix $\{\mathrm{ex}\}$ [emphasis mine, MHG] is phonetically/ek/ when the stem beings with /s/ preceding as in exceed versus extend" (Chomsky and Halle, 1968: 47). ${ }^{9}$

${ }^{9}$ Exemplary derivation involving ex proceeds as follows: e.g. exceed, excite from underlying stems as $/ \mathrm{ke} \mathrm{e} /$, /kit/, with $/ \mathrm{k} /$ turning to /s/ by Velar softening (this would actually be $\left[\mathrm{k}^{\mathrm{d}}\right]$ ). Then there will be an intermediate stage of the derivation, [eks=sīyd], [eks=sāyt], and finally a rule of cluster simplification would apply (a rule eliminating the first identical consonant in the geminate). There is thus no voicing in excel due to the fact that the rule voicing prestress consonants is blocked by the cluster of three consonants (Chomsky and Halle, 1968: 221f). We can clearly see the epistemological gist of generative grammar: the assumption that the underlying representations do not basically change but have to become more and more dissociated from any reality to account for the changes. This results in disregarding language diachrony and not bothering with whether the process in question might still be active or not. In short, this means that morphological rules are thrown into the mind of a competent speaker who has, in real time, to do all the concatenations, as in correlate, which, according to SPE, has an underlying representation with $/ \mathrm{koN}=/$. In Chomsky and Halle's words, "[i]t is a widely confirmed empirical fact that underlying representations are fairly resistant to historical change, which tends, by and large, to involve late phonetic rules" (Chomsky and Halle, 1968: 49). Not only exist is etymologically given as prefixated word (see for example http://en.wiktionary.org/wiki/exist, which says: from \{ex-\} 'out' and 'sistere' ("to set, place"), caus. of stare ("to stand"), also corroborated in Flemons, 1991: 21). As pointed out in e.g. Denning et al. (2007), concatenations with $\{$ ex- $\}$, just as $\{$ in- $\}$ and $\{$ con- $\}$, diachronically involved considerable assimilatory elisions, e.g. $e x+v a d e=$ evade, ex + mitt + ing $=$ emitting (Denning et al., 2007: 121). It means, that this fact should have been taken in underlying representation of event or evade. 


\section{Discussion and conclusions}

This brief overview shows that it is difficult to find an objective criterion according to which the two boundaries are assigned. There seems to be no classificatory principle that can be extracted from the forms. No criterion is mentioned for assigning boundaries, nor for being a formative. The traditional posterior interpretation of 'cranberry morphemes' does not seem to hold because, as shown in the queries of representations, both "+" and "=", go and can go with both content morphemes and semantically empty ones. 'Romance forms' could be a candidate; and indeed, this creation is vaguely mentioned in places in SPE; and yet, much Latinate vocabulary does not go with this boundary (e.g. corollary), and at the same time, words not suspected of having a Latinate origin do possess it (chimpanzee).

The most plausible explanation seems to be etymological criteria - i.e. taking from etymological sources lexemes which in Latin came into being concatenated. The problem is that the word 'etymology' never appears in SPE, and Chomsky and Halle do not mention etymological dictionaries as a source for their underlying representations. In fact, they do not mention any source for that, except for one instance, when Chomsky and Halle observe that forms such as e.g. unwise, overprice, anti-tax, which "consist of a prefix which is semantically and syntactically functional, combined with a full lexical form must not undergo a separate application of the cycle. (...) What is at issue is the problem of how fairly productive prefixes are to be described within a syntactic component of the grammar" (SPE: 106, footnote 59).

The etymological criterion can be assumed to hold for various, otherwise difficult to explain, cases, e.g. the difference between corollary and correlative (there is no ${ }^{*} c o=$ rollary). Let us recall that orthography is, for Chomsky and Halle, a viable means to uncover underlying representations. In this respect, the digraph $<$ rr $>$ in correlative might indeed point to a rule transforming the nasal into the rhotic, with a subsequent rule simplifying the cluster. The only way to test the underlying motifs would be to see an underlying representation of, e.g., coherent, which, orthographically, does not have any sign of a nasal which was already lost in Vulgar Latin times (cf. L. Zabrocki, 1980[1962]). The underlying representation of this would be a true "in flagranti crimine comprehesi": $\{\mathrm{co}-\}$ no longer has any semantic content in coherent, and it is a diachronic parallel of correlative or of symbol. If the proposed form was $/ \mathrm{k} v \mathrm{~N}=/$, then the 'etymological machinery' would became obvious. Regretfully, neither representations of symbol nor coherence feature at all in SPE. Still, if Chomsky and Halle did check etymological dictionaries in proposing their underlying representations, they did a very poor job of that, since in SPE e.g. recondite does not have ' $=$ ', nor does collective have /collect+ive/, and yet it also derives from com + legere. 
Above, also see dysentery /disVntAr+y/, etymologically as $d y s+$ entera. Illustrative does not have a boundary according to SPE, yet it comes in exactly the same way from $\{$ in- $\}+\{$ lustrare $\}$. Neither has advocacy any boundary assigned, although it comes from Latin $\{$ ad- $\}+\{$ vocare $\}$.

On the other hand, the $/ \mathrm{k} \mathrm{NN} /$ as a proposed underlying representation for, e.g. correlative, implies that for Chomsky and Halle, synchronically, English grammar still has a concatenation in correlative. This is in fact one of the epistemological pivots of generativist thought. Bynon (1977) captures it concisely when she mentions that the key difference between the representation of sound change in Neogrammarian and structuralist models lies in the pace with which lexical items are restructured as a consequence of sound change. In particular, "[w] hereas in the former models lexical representations are restructured immediately, in the transformational model it can be a very much slower process" (Bynon, 1977: 121). ${ }^{10}$

Given the data discussed above, my claim here is that '=' an entity which phenomenologically can be called one of the coefficients hidden in SPE. We have to recall here that $S P E$ contains quite a lot of exotic gimmicks, which usually go unnoticed in subsequent exegeses. For example, there is $(+D)$ which can mark certain rules, just as phi in $/ \mathfrak{r v e n}^{\varphi}$, $\operatorname{reven}^{\varphi}, \mathrm{re}=\operatorname{sid}^{\varphi}$ and $\mathrm{k} \supset \mathrm{N}=\operatorname{tin}^{\varphi} /$, or [+regular] marking on verbs, or [+F] marking on, e.g., satisfy. Thus we can see here how the language of maths is directly incorporated into a phonological theory: "=" functions exactly as a mathematical coefficient. The reason for the "=" /',' distinction is thus purely formulaic: both $[+\mathrm{FB}]$ and $[+\mathrm{WB}]$ have a specific formation which the rules are sensitive to. What follows, [-FB] can block a rule from applying, e.g. '=' can block the Main Stress Rule from applying under certain conditions (sometimes with the help of $[+D)$ (e.g. Chomsky and Halle, 1968: 98). There is no independent motivation for its existence apart from the fact that words of the type, e.g., worship and permit must be differentiated somehow in order to account for their different behaviours. The dichotomy of '=' versus '+', simply "does the job". ${ }^{11}$

${ }^{10}$ Furthermore, ,the ordinary innovatory sound changes of traditional historical linguistics are represented in the transformational model as the addition of new phonological rules situated at the end of the phonological component and operating on the systematic phonetic realizations. The addition of such a rule may lead to subsequent restructuring if a simpler rule system is capable of producing an identical output. This restructuring process consists in the transfer of the effect of the added rule to the underlying representations in the lexicon" (Bynon (1996 [1977]): 21).The same reference for a critique of this procedure.

${ }^{11}$ Also, perhaps a more clear example is SPE work on /s/ voicing: according to Chomsky and Halle, the ' $=$ ' boundary in consume or consist (con=sist) blocks the operation of voicing, yet the same boundary is actually the factor that triggers voicing intervocalically (resign). Furthermore, for the purposes of the SPE's (119) rule, there is no '=' boundary in exam but the concatenation is 


\section{Bibliography}

Archangeli, D. (ed.). 1997. Optimality theory: an overview. Oxford: Blackwell.

Bańczerowski, J. 2004. „Prądy aksjomatyzacyjne w językoznawstwie”. Scripta Neophilologica Posnaniensia 6. 15-72.

Bussmann, H. 1996. Routledge dictionary of language and linguistics. [Translated by Gregory Trauth and Kerstin Kazzazi]. London: Routledge.

Bynon, T. 1996 [1977]. Historical linguistics. Cambridge: Cambridge University Press.

Carr, P. 1993. Phonology. London: Macmillan.

Chomsky, N. 1957. Syntactic structures. The Hague: Mouton de Gruyter.

Chomsky, N., Halle, M. and F. Lukoff. 1956. "On accent and juncture in English". In: Halle, M., Lunt, H.G., McLean, H. and C.H. van Schooneveld. (eds). For Roman Jakobson. Essays on the occasion of his sixtieth birthday. The Hague: Mouton. 65-80.

Chomsky, N. and M. Halle. 1968. The sound pattern of English. New York: Harper and Row.

Cummings, D.W. 1988. American English spelling. Baltimore: The Johns Hopkins University Press.

Denning, K., Kresler, B. and W. Leben. 2007 [1995]. English vocabulary items. Oxford: Oxford University Press.

Flemons, D. 1991. Completing distinctions. Boston: Shambhala.

Goldsmith, J., Riggle, J. and A. Yu (eds.). 2011 [1995]. The handbook of phonological theory. Malden: Wiley-Blackwell.

Haładewicz-Grzelak, M. and L. Tendera. 2008. "Logic in optimal places: linguistic platonism". Beyond Philology 5. 23-53.

Kiklewicz, A. 2007. Zrozumieć język. Szkice z filozofii języka, semantyki, lingwistyki komunikacyj$n e j$. Łask: Oficyna Wydawnicza LEKSEM.

Kuźniak, M. 2013. "Newton, cognitive linguistics and other things". [paper read at the International Conference Post Newtonian models of the world and new paradigms in language and communication studies (Olsztyn: UWM, 2-3 września 2013).

Prince, A. and P. Smolensky. 1993. Optimality theory - constraint interaction in generative grammar. New Brunswick: Rutgers University Press.

Scheer, T. 2011. A guide to morphosyntax-phonology interface theories. Berlin: Mouton de Gruyter.

Siegel, D. 1974. Topics in English morphology. Cambridge, Mass: The MIT Press.

Skeat, W. 1993. The concise dictionary of English etymology. Ware: Wordsworth Editions.

Wąsik, Z. 2005. „Język, języki czy właściwości językowe członków wspólnot komunikatywnych w przedmiocie badań lingwistycznych?”. Scripta Neophilologica Posnaniensia 7. 195-212.

Wierzbicka, A. 1978. „Słowo wstępne”. In: Sapir, E. Kultura, język, osobowość. Wybór pism [translated by Barbara Stanosz and Roman Zimand]. Warszawa: PIW.

Zabrocki, L. 1980 [1962]. „Stabilność spółgłosek nosowych w rozwoju historycznym”. In: Bańczerowski, J. (ed.). Ludwik Zabrocki. U podstaw struktury i rozwoju języka. Warszawa: PWN. 192-243.

referred to as prefixal on many other occasions throughout SPE. Hence the = boundary blocks assimilation in consist, does not block it in exam (or is transparent or inactive, actually phrased as nonexistent) and triggers the assimilation in e.g. resign. 